\title{
ARAŞTIRMA / RESEARCH \\ Determining the knowledge levels of secondary education students on tuberculosis before and after training
}

\author{
Ortaöğretim öğrencilerinde eğitim öncesi ve sonrası tüberküloz hakkındaki bilgi \\ düzeylerinin belirlenmesi
}

\section{Pinar Etiz 1 iD}

${ }^{1}$ Cukurova University, Abdi Sutcu Vocational School of Health Services, Adana, Turkey

Cukurova Medical Journal 2021;46(4):1369-1378

\begin{abstract}
Purpose: This study aims to evaluate the results of the training about tuberculosis given to secondary school students and to compare the knowledge levels of the students who received the aforementioned training before and after the training depending on various variables.

Materials and Methods: The universe of this descriptive study consists of 700 students studying in a secondary education institution affiliated with the Ministry of National Education in Adana. The sample, on the other hand, consisted of 600 students who are volunteered to participate in the study. Personal information form and tuberculosis information form are used as data collection tools in the study, and the data are obtained in the 20172018 academic year.

Results: While females constitute $57.5 \%$ of 600 students participating in the study, males constitute $42.5 \%$. The average age of the students is $16.45 \pm 1.08$ years. The percentages of the tuberculosis knowledge level of the students before the training vary between 10 and 100 and the average is $59.31 \pm 15.61$. The percentages of the tuberculosis knowledge level of the students after the training vary between 70 and 100 and the average is $95.30 \pm 7.35$. The average percentage of tuberculosis knowledge level after training was found statistically significantly higher than that of the pre-training level.

Conclusion: The increases in the correct answer to all questions in the questionnaire after the training compared to the pre-training level were found to be statistically significant.
\end{abstract}

Keywords:. Knowledge, students, questionnaire, tuberculosis
Öz

Amaç: Bu çalışmada, ortaöğretimde öğrenim gören öğrencilere tüberkülozla ilgili verilen eğitimin sonuçlarının değerlendirilmesi ve bahsi geçen eğitimi alan öğrencilerde eğitim öncesi ve sonrası, çeșitli değişkenlere bağlı olarak bilgi düzeylerinin karşılaştırılması amaçlanmıştır.

Gereç ve Yöntem: Tanımlayıcı nitelikte olan bu çalışmanın evrenini Adana ilinde Milli Eğitim Bakanlığına bağlı bir orta öğretim kurumunda öğrenim gören 700 öğrenci oluşturmuştur. Örneklemi ise araştırmaya katılmaya gönüllü 600 öğrenciden oluşmuştur. Araştırmada veri toplama aracı olarak kişisel bilgi formu ve tüberküloz bilgi formu kullanılmış, veriler 2017-2018 öğretim yllında elde edilmiștir.

Bulgular: Çalışmaya katılan 600 öğrencinin \%57,5'i kadın, $\% 42,5$ 'i erkektir. Öğrencilerin yaș ortalaması $16,45 \pm 1,08$ yıldır. Öğrencilerin eğitim öncesi tüberküloz bilgi düzeyi yüzdeleri 10 ile 100 arasında değişmekte olup, ortalaması $59,31 \pm 15,61$ 'dir. Eğitim sonrasinda ise tüberküloz bilgi düzeyi yüzdeleri 70 ile 100 arasında değişmekte olup, ortalaması $95,30 \pm 7,35$ 'tir. Eğitim sonrası tüberküloz bilgi düzeyi yüzde ortalaması, eğitim öncesinden istatistiksel olarak anlamlı düzeyde yüksek saptanmışır.

Sonuç: Öğrencilerin eğitim öncesine göre eğitim sonrasinda ankette verilen tüm sorulara doğru cevap verme oranlarında görülen artışlar istatistiksel olarak anlamlı saptanmıştır.

Anahtar kelimeler: Anket, bilgi düzeyi, öğrenciler, tüberküloz 


\section{INTRODUCTION}

Tuberculosis is an infectious disease caused by Mycobacterium tuberculosis bacillus, which tends to settle mostly in the lungs and lymph nodes, although it can involve many organs, and causes inflammation with a granulomatous character ${ }^{1}$. Tuberculosis is the main cause of death caused by a single infectious agent and is one of the 10 most common causes of deaths worldwide ${ }^{2}$. Its frequency has decreased significantly in the last hundred years, but despite all global efforts to control and prevent the disease, it continues to be an important public health problem for underdeveloped countries and developing countries including Turkey ${ }^{1,3}$. According to the data of the World Health Organization (WHO), 7.1 million new tuberculosis cases were officially registered in $2019^{2}$. The 7.1 million cases reported represent $71 \%$ of the 10 million new cases estimated in 2019. Globally, it has been reported that there has been an increase in the annual number of people receiving tuberculosis treatment in recent years. While this number was approximately 6 million in 2015, it reached 7.0 million in 2018 and 7.1 million in $2019^{2}$. Although its agent, diagnosis and treatment are known, the fact that it is still such an important problem shows that this issue should be approached with care and attention all over the world 4 .

In addition to being the leading cause of workforce loss and deaths in the world, tuberculosis is an important public health problem since it is a communal and social disease ${ }^{5}$. Tuberculosis patients are stigmatized due to their diseases and this causes the patients not to benefit from diagnosis and treatment opportunities adequately and the disease cannot be controlled at the social level ${ }^{6}$. Misconceptions and prevention methods about tuberculosis may cause isolation and exclusion of tuberculosis patients from society. Informing people who do not have tuberculosis disease will remove the pressure of society in the treatment of tuberculosis patients and will play an important role in preventing new individuals from becoming infected and controlling tuberculosis by applying protective measures ${ }^{7}$. In the fight against tuberculosis, which has such serious consequences, it is very important to increase the tenderness and knowledge level of the society. The most effective way to prevent the spread of it is protection. The main point in protection is training. It is thought that our young people, who are our target audience, have sufficient and correct information, will be possible by holding meetings on issues concerning public health intermittently and informing them and by training, which is the cornerstone of preventive healthcare services ${ }^{8}$. Therefore, it is thought that determining the level of knowledge of our youth about tuberculosis and providing training periodically and updating their knowledge will be beneficial to win the war with tuberculosis. Besides all these, to be known the clinical findings related to tuberculosis by the society will enable them to apply to health institutions early, and help the patient's family and people around them to be protected from the disease with early diagnosis and treatment ${ }^{7}$. We can think that students are also in the risk group, as they spend a lot of time in communal living places such as dormitories and schools. In the 2019 diagnosis and treatment guide of the Ministry of Health, it is stated that people who share the same room with a tuberculosis patient in public places such as schools, dormitories, barracks, detention centers and prisons, and those who travel eight hours by plane with infectious tuberculosis patients are also accepted as contacted ${ }^{9}$. It was reported that there was an epidemic of tuberculosis among students studying at a university in Ethiopia in $2015^{10}$. In the study of Ma et al., 46 active cases were found among 258 students and 15 teachers/staff in a secondary school in China ${ }^{11}$. For all these reasons, providing students with training to increase their knowledge level for prevention and treatment of tuberculosis is a simple but effective method in combating tuberculosis. Studies evaluating the level of knowledge about tuberculosis in Turkey have generally been conducted on physicians, healthcare professionals and university students. In this planned study, all of the participants are secondary school students who will soon start university education or directly start working life. No such study targeting secondary school students in Turkey has been found in the literature reviews. It is believed that researches determining the level of knowledge of the young adult population about tuberculosis disease will contribute to a more realistic solution in the control of tuberculosis ${ }^{7}$. Therefore, the study aims to evaluate the results of the training about tuberculosis given to students studying in secondary education and compare the knowledge levels of the students who have received the aforementioned training before and after the training depending on various variables.

As a result of the literature reviews, this study is the first study conducted at national level to evaluate the knowledge about tuberculosis of students studying outside the field of health sciences. Accordingly, it is 
thought that the findings of this study will increase awareness in the fight against tuberculosis and will be a guide in the design and implementation of the training programs to be carried out.

\section{MATERIALS AND METHODS}

\section{Participants}

This study is a descriptive type of research that aims to evaluate the knowledge levels of secondary school students $\left(9^{\text {th }}, 10^{\text {th }}, 11^{\text {th }}\right.$, and $12^{\text {th }}$ grade) before and after the tuberculosis training given to them, depending on various variables. The population of the research consisted of 700 students studying in a secondary education institution affiliated to the Ministry of National Education in Adana in the 20172018 academic year. The sample of the study consists of 600 students who volunteered to participate in the study. Before the implementation process, necessary permissions were obtained from the Provincial Directorate of National Education and the school administration was informed about the research. Before the implementation of the training program, students and their parents were informed and written consent was obtained from the parents. Students did not pay any fees for participation in the training program. The pre-tests were applied before the tuberculosis training program started, and the posttests one month after the end of the training program.

Ethical approval for this research was obtained from the ethical review committee of Cukurova University Medical Faculty in accordance with the Helsinki Recommendations (document no: 2017/63/17, date: 04./14/2017).

\section{Study design}

Participants participated in a 2 -session tuberculosis training program conducted by the researcher, each lasting 60 minutes. During the sessions, various visual aids such as power point presentations, posters and charts were used in the implementation of the activities. In the first session, the training program and its aim were explained to the students and a pretest was applied. In the second session, general tuberculosis training was given. The contents of the tuberculosis training program consisted of how tuberculosis is transmitted, which organ most frequently affects, what its symptoms are, how it is diagnosed, the duration and cost of the treatment, the effectiveness of the Bacillus Calmette Guerin (BCG) vaccine and the periods of life it was used, and directly observed treatment (DOT). Both these trainings and tests were done face to face.

The sample size was calculated using the formula, $n=\frac{N t^{2} p q}{d^{2}(N-1)+t^{2} p q}$ size, $\mathrm{n}=$ sample size, $\mathrm{t}=$ confidence level for student$\mathrm{t}$ distribution, $\mathrm{p}=$ estimated proportion and $\mathrm{d}=$ absolute error) ${ }^{12}$. Taking population size of 700 , a confidence interval (CI) of 95\% interval, with a probability of $50 \%$ and margin of error at $1 \%$ and a considering non-response rate, the sample size was rounded off to 600 .

\section{Measures}

A questionnaire form was used to collect data in the study. The questionnaire form consists of two parts. The first part includes questions about demographic characteristics, and the second part includes questions for measuring the knowledge levels of the participating students about tuberculosis. The students participating in the questionnaire were asked to write their names on the questionnaire forms applied before and after the training. Thus, the preand post-training knowledge of the students was evaluated. While applying the questionnaire, the students were asked to mark an option they thought to be correct. The questionnaire forms were applied in the classroom under the supervision of the researcher.

\section{Personal information form}

There were 10 questions prepared by the researcher regarding the socio-demographic characteristics (age, gender, grade of education, whether they and/or their family members have a history of tuberculosis, etc.) of the participants in the personal information form.

\section{Tuberculosis information form}

Since the tuberculosis information form is not a national or international standard questionnaire measuring the tuberculosis knowledge level (contagiousness and transmission routes of tuberculosis, obligation to notify, which organ most frequently affects, what the symptoms of the disease are, how it is diagnosed, cost of treatment and directly supervised treatment), it consists of 10 multiplechoice questions prepared by the researcher to determine the basic tuberculosis knowledge level of the students. While creating the questions, it was paid 
attention to have very general information about tuberculosis.

\section{Statistical analysis}

While evaluating the findings obtained in the study, IBM SPSS Statistics 22 (IBM SPSS, Turkey) program was used for statistical analysis. The compatibility of the variables to normal distribution was evaluated using the Shapiro Wilks test. Student-t test was used for the evaluation of quantitative data between the two groups in addition to descriptive statistical methods (mean, standard deviation, frequency) while evaluating the study data. One-way ANOVA test was used in the evaluation of quantitative data between more than two groups, and the Tukey HSD post-hoc test was used to identify the group that caused the difference. Paired Sample-t test was used to evaluate the quantitative data before and after the training. McNemar test was used to evaluate qualitative data. Significance was evaluated at the $\mathrm{p}<0.05$ level.

\section{RESULTS}

The study was conducted with a total of 600 secondary school students, $57.5 \% \quad(n=345)$ female and $42.5 \%(n=255)$ male. The ages of the students vary between 15 and 19 years and the average are $16.45 \pm 1.08$ years. The distribution of general characteristics of students is given in Table 1 . According to the detected data, $29.8 \%$ of the students $(n=179)$ are 17 years old, $57.5 \%(n=345)$ of them are female, $29.5 \% \quad(n=177)$ of them are $11^{\text {th }}$ grade students, $0.3 \% \quad(n=2)$ of them had a history of tuberculosis, $3.8 \%(n=23)$ had a family history of tuberculosis, and $82.6 \%$ of these people $(n=19)$ were found to be family members other than mother and father.

The evaluation of the tuberculosis knowledge level rates of the students before and after the training is summarized in Table 2. The increases in the correct answer to all questions given in the questionnaire after the training compared to the pre-training level were found to be statistically significant (p:0.001; $\mathrm{p}<0.01)$.

The percentages of the tuberculosis knowledge level of the students before training varies between 10 and 100 and the average is $59.31 \pm 15.61$. The percentages of the tuberculosis knowledge level of the them after training vary between 70 and 100 and the average is $95.30 \pm 7.35$. The average percent of knowledge level of students on tuberculosis after training was found to be statistically significantly higher than before the training (p:0.001; $\mathrm{p}<0.01$ ) (Table 3).

The evaluation of tuberculosis knowledge level percentages before and after training according to age groups is given in Table 4 . There was no statistically significant difference between the age groups in terms of the pre-training level of tuberculosis knowledge percentage averages $(p>0.05)$. On the other hand, there was statistically significant difference between the age groups in terms of the post-training level of tuberculosis knowledge percentage averages (p: 0,026; $<<0,05)$. As a result of the paired post-hoc comparisons made to determine from which group the difference originated, the average percentage of tuberculosis knowledge of 17year-olds after training was found to be significantly higher than those of 15-year-olds (p:0.017; p<0.05). There was no significant difference between the other age groups in terms of the percentage average of tuberculosis knowledge level after training ( $p>0.05)$. No statistically significant difference was found between all age groups in terms of the amount of change observed in the percentage of tuberculosis knowledge level after training compared to pretraining $(\mathrm{p}>0.05)$ (Table 4).

According to Table 5, no statistically significant difference was found between the percentage averages of the tuberculosis knowledge level before and after the training according to gender in the students participating in the study $(\mathrm{p}>0.05)$. In both male and female, the increases seen in the percentage of tuberculosis knowledge level after training compared to pre-training were found to be statistically significant ( $\mathrm{p}: 0.001 ; \mathrm{p}<0.01)$.

According to Table 6, statistically significant difference was not found between the grades in which the students participating in the study were educated in terms of the pre-training level of tuberculosis knowledge percentage averages $(p>0.05)$. After the training, on the other hand, a statistically significant difference was found in terms of the mean percentage of tuberculosis knowledge level ( $p: 0.028 ; p<0.05)$. As a result of the paired posthoc comparisons made to determine from which group the difference originated, the average posttraining level of tuberculosis knowledge of $11^{\text {th }}$ grade students was found to be significantly higher than those of $9^{\text {th }}$ grade students $(\mathrm{p}: 0.029 ; \mathrm{p}<0.05)$. There was no significant difference between the other grades in terms of the percentage of tuberculosis knowledge level after training $(\mathrm{p}>0.05)$. Statistically 
significant difference was not found between the grades in terms of the amount of change observed in the percentage of tuberculosis knowledge level after training compared to pre-training $(\mathrm{p}>0.05)$. The increases observed in the percentages of tuberculosis knowledge level of students studying in all grades $\left(9^{\text {th }}\right.$, $\left.10^{\text {th }}, 11^{\text {th }}, 12^{\text {th }}\right)$ after training compared to pre-training were found to be statistically significant (p:0.001; $\mathrm{p}<0.01$ ). The evaluation of tuberculosis knowledge level percentages before and after the training according to whether there is a history of tuberculosis disease in the family is given in Table 7.

Table 1. General characteristics of students $(n=600)$

\begin{tabular}{|c|c|c|c|}
\hline & & Min-Max & Mean \pm SD \\
\hline \multirow[t]{2}{*}{ Age (year) } & & $15-19$ & $16.45 \pm 1.08$ \\
\hline & & $\mathrm{n}$ & $\%$ \\
\hline \multirow[t]{4}{*}{ Age Group } & 15 years & 147 & 24.5 \\
\hline & 16 years & 156 & 26.0 \\
\hline & 17 years & 179 & 29.8 \\
\hline & $\geq 18$ years & 118 & 19.6 \\
\hline \multirow[t]{2}{*}{ Gender } & Female & 345 & 57.5 \\
\hline & Male & 255 & 42.5 \\
\hline \multirow[t]{4}{*}{ Class } & $9^{\text {th }}$ Grade & 155 & 25.8 \\
\hline & $10^{\text {th }}$ Grade & 150 & 25.0 \\
\hline & 11,th Grade & 177 & 2.5 \\
\hline & $12^{\text {th }}$ Grade & 118 & 19.7 \\
\hline \multirow{2}{*}{$\begin{array}{l}\text { Participants who had been diagnosed with } \\
\text { tuberculosis }\end{array}$} & Yes & 2 & 0.3 \\
\hline & $\mathrm{No}$ & 598 & 99.7 \\
\hline \multirow{2}{*}{$\begin{array}{l}\text { Participants who had a family history of } \\
\text { tuberculosis }\end{array}$} & Yes & 23 & 3.8 \\
\hline & No & 577 & 96.2 \\
\hline \multirow{3}{*}{$\begin{array}{l}\text { Tuberculosis patients in the participants } \\
\text { family }(\mathrm{n}=23)\end{array}$} & Mother & 1 & 4.3 \\
\hline & Father & 3 & 13.0 \\
\hline & Other & 19 & 82.6 \\
\hline
\end{tabular}

Table 2. Evaluation of the tuberculosis knowledge level of the students before and after training $(n=600)$

\begin{tabular}{|c|c|c|c|c|}
\hline \multirow{2}{*}{\multicolumn{2}{|c|}{ Tuberculosis knowledge level questions }} & \multirow{3}{*}{$\begin{array}{c}\text { Pre-training } \\
\mathrm{n}(\%) \\
517(86.2 \%) \\
\end{array}$} & \multirow{3}{*}{$\begin{array}{c}\text { Post-training } \\
\mathrm{n}(\%) \\
600(\% 100 \%) \\
\end{array}$} & \multirow[t]{2}{*}{ p-value } \\
\hline & & & & \\
\hline \multirow[t]{2}{*}{ Is tuberculosis communicable disease? } & True & & & \multirow[t]{2}{*}{-} \\
\hline & False & $83(13.8 \%)$ & - & \\
\hline \multirow[t]{2}{*}{ Is tuberculosis a notifiable disease? } & True & $451(75.2 \%)$ & $587(97.8 \%)$ & \multirow[t]{2}{*}{$0.001 * *$} \\
\hline & False & $149(24.8 \%)$ & $13(2.2 \%)$ & \\
\hline \multirow[t]{2}{*}{ Is tuberculosis a treatable disease? } & True & $548(91.3 \%)$ & $599(99.8 \%)$ & \multirow[t]{2}{*}{$0.001 * *$} \\
\hline & False & $52(8.7 \%)$ & $1(0.2 \%)$ & \\
\hline \multirow{2}{*}{$\begin{array}{l}\text { What is the germ which causes } \\
\text { tuberculosis? }\end{array}$} & True & $116(19.3 \%)$ & $551(91.8 \%)$ & \multirow[t]{2}{*}{$0.001 * *$} \\
\hline & False & $484(80.7 \%)$ & $49(8.2 \%)$ & \\
\hline \multirow[t]{2}{*}{ How tuberculosis is transmitted? } & True & $405(67.5 \%)$ & $594(99 \%)$ & \multirow[t]{2}{*}{$0.001^{* *}$} \\
\hline & False & $195(32.5 \%)$ & $6(1 \%)$ & \\
\hline \multirow[t]{2}{*}{ Which organ can be affect frequently? } & True & $520(86.7 \%)$ & $596(99.3 \%)$ & \multirow[t]{2}{*}{$0.001 * *$} \\
\hline & False & $80(13.3 \%)$ & $4(0.7 \%)$ & \\
\hline \multirow{2}{*}{$\begin{array}{l}\text { What is the most common symptom of } \\
\text { pulmonary (tuberculosis of the lungs) } \\
\text { tuberculosis? }\end{array}$} & True & $246(41 \%)$ & $548(91.3 \%)$ & \multirow[t]{2}{*}{$0.001^{* *}$} \\
\hline & False & $354(59 \%)$ & $52(8.7 \%)$ & \\
\hline \multirow{2}{*}{$\begin{array}{l}\text { How is the diagnosis of pulmonary } \\
\text { tuberculosis? }\end{array}$} & True & $316(52.7 \%)$ & $541(90.2 \%)$ & \multirow[t]{2}{*}{$0.001^{* *}$} \\
\hline & False & $284(47.3 \%)$ & $59(9.8 \%)$ & \\
\hline \multirow{2}{*}{$\begin{array}{l}\text { Does the patient pay for tuberculosis } \\
\text { treatment? }\end{array}$} & True & $307(51.2 \%)$ & $595(99.2 \%)$ & \multirow[t]{2}{*}{$0.001 * *$} \\
\hline & False & $293(48.8 \%)$ & $5(0.8 \%)$ & \\
\hline \multirow{2}{*}{ What is the meaning of DOTS? } & True & $133(22.2 \%)$ & $507(84.5 \%)$ & \multirow[t]{2}{*}{$0.001 * *$} \\
\hline & False & $467(77.8 \%)$ & $93(15.5 \%)$ & \\
\hline
\end{tabular}

Since the McNemar Test uses Binomial Distribution, the test value cannot be calculated, so only p values are given;McNemar Testi ${ }^{* *} \mathrm{p}<0.01$ 
Table 3. The evaluation of the tuberculosis knowledge levels of the students before and after the training in terms of percentage of correct answers

\begin{tabular}{|c|c|c|c|c|}
\hline & \multicolumn{2}{|c|}{ Tuberculosis knowledge level (\%) } & \multirow[t]{2}{*}{$\mathrm{t}$} & \multirow[t]{2}{*}{ p-value } \\
\hline & Min-Max & Mean \pm SD & & \\
\hline Pre-training & $10-100$ & $59.32 \pm 15.61$ & \multirow[t]{2}{*}{56.184} & \multirow[t]{2}{*}{$0.001^{* *}$} \\
\hline Post-training & $70-100$ & $95.30 \pm 7.35$ & & \\
\hline
\end{tabular}

Table 4. Evaluation of tuberculosis knowledge level percentages before and after training by age groups

\begin{tabular}{|l|c|c|c|c|c|c|}
\hline \multirow{2}{*}{} & \multicolumn{3}{|c|}{ Age Group } & \multirow{2}{*}{ F } & \multirow{2}{*}{ p-value } \\
\cline { 2 - 5 } & 15 years & 16 years & 17 years & $\geq 18$ years & & \\
\cline { 2 - 5 } & Mean \pm SD & Mean \pm SD & Mean $\pm S D$ & Mean \pm SD & & \\
\hline Pre-training & $58.98 \pm 13.07$ & $61.22 \pm 16.00$ & $58.88 \pm 15.17$ & $57.88 \pm 18.39$ & 1.173 & 0.319 \\
\hline Post-training & $93.81 \pm 8.22$ & $95.26 \pm 7.31$ & $96.09 \pm 6.47$ & $96.02 \pm 7.30$ & 3.113 & $0.026^{*}$ \\
\hline Difference & $34.83 \pm 13.47$ & $34.04 \pm 15.61$ & $37.21 \pm 15.14$ & $38.14 \pm 18.67$ & 2.180 & 0.089 \\
\hline $\mathrm{t}$ & -31.362 & -27.240 & -32.878 & -22.186 & & \\
\hline $\mathrm{p}$ & $0.001 * *$ & $0.001^{* *}$ & $0.001^{* *}$ & $0.001^{* *}$ & & \\
\hline
\end{tabular}

F: One-way ANOVA t: Paired Sample-t Test ${ }^{*} \mathrm{p}<0.05 * * \mathrm{p}<0.01$

Table 5. Evaluation of tuberculosis knowledge level percentages before and after training by gender

\begin{tabular}{|l|c|c|c|c|}
\hline & \multicolumn{2}{|c|}{ Gender } & \multirow{2}{*}{${ }^{1} \mathrm{t}$} & \multirow{2}{*}{$\mathrm{p}$-value } \\
\hline & Female & Male & \\
\hline & Mean \pm SD & Mean \pm SD & & \\
\hline Pre-training & $59.74 \pm 15.63$ & $58.75 \pm 15.60$ & 0.771 & 0.441 \\
\hline Post-training & $95.74 \pm 7.12$ & $94.71 \pm 7.62$ & 1.705 & 0.089 \\
\hline Difference & $36.00 \pm 15.65$ & $35.96 \pm 15.77$ & 0.030 & 0.976 \\
\hline${ }^{2} \mathrm{t}$ & $\mathbf{- 4 2 . 7 2 0}$ & $\mathbf{- 3 6 . 4 2 2}$ & & \\
\hline $\mathrm{p}$ & $\mathbf{0 . 0 0 1 * *}$ & $\mathbf{0 . 0 0 1 * *}$ & & \\
\hline
\end{tabular}

Table 6. Evaluation of tuberculosis knowledge level percentages before and after training according to grade levels

\begin{tabular}{|l|c|c|c|c|c|c|}
\hline \multirow{2}{*}{} & \multicolumn{4}{|c|}{ Class } & \multirow{2}{*}{ F } & \multirow{2}{*}{ p-value } \\
\cline { 2 - 5 } & $9^{\text {th }}$ grade & $10^{\text {th }}$ grade & $11^{\text {th }}$ grade & $12^{\text {th }}$ grade & & \\
\cline { 2 - 5 } & Mean \pm SD & Mean \pm SD & Mean \pm SD & Mean \pm SD & & \\
\hline Pre-training & $58.58 \pm 13.07$ & $61.80 \pm 16.06$ & $58.81 \pm 15.16$ & $57.88 \pm 18.39$ & 1.780 & 0.150 \\
\hline Post-training & $93.87 \pm 8.17$ & $95.27 \pm 7.30$ & $96.10 \pm 6.49$ & $96.02 \pm 7.30$ & 3.063 & $0.028^{*}$ \\
\hline Difference & $35.29 \pm 13.74$ & $33.47 \pm 15.37$ & $37.29 \pm 15.17$ & $38.14 \pm 18.67$ & 2.556 & 0.054 \\
\hline $\mathrm{t}$ & -31.983 & -26.668 & -32.704 & -22.186 & & \\
\hline $\mathrm{p}$ & $0.001 * *$ & $0.001^{* *}$ & $0.001 * *$ & $0.001^{* *}$ & & \\
\hline
\end{tabular}

F: One-way ANOVA t: Paired Sample-t Test ${ }^{*} \mathrm{p}<0.05{ }^{* *} \mathrm{p}<0.01$

Table 7. Evaluation of the percentages of tuberculosis knowledge level before and after the training according to the family history of tuberculosis

\begin{tabular}{|l|c|c|c|c|}
\hline & \multicolumn{2}{|c|}{ Family history of tuberculosis } & \multirow{2}{*}{ 1 } & \multirow{2}{*}{ p-value } \\
\cline { 1 - 3 } & Yes & No & & \\
\cline { 1 - 3 } & Mean \pm SD & Mean \pm SD & & \\
\hline Pre-training & $79.13 \pm 17.03$ & $58.53 \pm 15.04$ & 6.411 & $0.001^{* *}$ \\
\hline Post-training & $97.39 \pm 6.19$ & $95.22 \pm 7.38$ & 1.393 & 0.164 \\
\hline Difference & $18.26 \pm 14.35$ & $36.69 \pm 15.33$ & -5.666 & $0.001^{* *}$ \\
\hline${ }^{2} \mathrm{t}$ & -6.103 & -57.487 & & \\
\hline $\mathrm{p}$ & $0.001^{* *}$ & $0.001^{* *}$ & & \\
\hline
\end{tabular}


The average pre-training level of tuberculosis knowledge in those with a family history of tuberculosis was found to be statistically significantly higher than those without it ( $\mathrm{p}: 0.001 ; \mathrm{p}<0.01)$. The increases in the percentage of tuberculosis knowledge level after training were found to be statistically significant in those with and without a family history of tuberculosis disease (p:0.001; $\mathrm{p}<0.01)$ (Table 7).

\section{DISCUSSION}

Tuberculosis is an important clinical condition with epidemiological and socioeconomic consequences that can significantly affect human quality of life. Its treatment is very important for both the individual and the society. Since tuberculosis is a communal and social disease, these two important elements can direct tuberculosis to a process that cannot be easily expressed and, when detected, can push the person back from social relations. The contagiousness of the disease can cause anxiety over patients and their environment. Sometimes incorrect or exaggerated information about the disease can also increase this anxiety ${ }^{8,13}$. Therefore, the effect of training on young people should not be ignored throughout their school and professional life. The increase in accuracy rates of the answers received after the training have been revealed the importance of training in this study.

When there is a lack of knowledge about tuberculosis, the information gap should be filled with training. In addition to closing the information gap, information needs to be put into practice and create a change in behavior ${ }^{14}$. In the study of Değer et al. on the students of the School of Health in which the level of knowledge about tuberculosis was determined, the knowledge levels of the students before and after the two-day tuberculosis training were determined and as a result, it was found that the knowledge about tuberculosis increased thanks to the training ${ }^{8}$. Also in this study, the increases in the correct response rates of the students to all questions in the questionnaire after the training compared to before the training were found to be statistically significant. Based on this finding, training programs on public health issues should be organized in order to raise awareness of the masses, to increase the knowledge of tuberculosis, and to raise awareness ${ }^{15}$.

In the study conducted by Gothankar in India, the average pre-test score of the students was 6.31 $(52.58 \%)$, and the average post-test score was 10.20 $(85 \%)^{16}$. In the study conducted by Dorji et al. with trainee teachers in Bhutan, the average general knowledge score of the participants was found to be 10.66 (range $0-21$ ). While $58.6 \%$ of the participants had a low level of knowledge of tuberculosis (score $<11.5$ ) (mean score $7.8 \pm 2.5$ ), the knowledge level of $41.4 \%$ was rated as agreeable ${ }^{17}$. In studies conducted in Bangladesh, Nigeria, Ethiopia and India, the tuberculosis knowledge level of the participants was found to be low. These countries are countries with high tuberculosis burden. One of the main reasons for this is their late admission to health institutions due to their limited knowledge of tuberculosis, and thus the delay in diagnosis ${ }^{18,19,20,21,22}$. In the study of Yilmaz et al., the average score of the tuberculosis knowledge level of the nurses was determined as 78.66 \pm 15.14 (min: 35-max: 100) ${ }^{23}$. In the study conducted by Çiftçi et al. in Turkey, the average knowledge-score before training was found to be $71.2 \pm 18.1$ (over 120 points), and $77.1 \pm 18.7$ after training. A significant increase was found in the knowledge-score between before and after the training (p:0.001) ${ }^{24}$. In this study, on the other hand, the average knowledge level of the students on tuberculosis before training was $59.31 \pm 15.61$, and the average knowledge level was found to be $95.30 \pm 7.35$ after the training.

In this study, the average percentage of tuberculosis knowledge level of 17-year-old students after training was found to be significantly higher than that of 15year-olds ( $\mathrm{p}: 0.017 ; \mathrm{p}<0.05)$. There was no significant difference between the other age groups in terms of the percentage average of tuberculosis knowledge level after training $(p>0.05)$. In the study of Polat et al., Nurses aged thirty and under have less knowledge about tuberculosis than others ${ }^{14}$. In the study of Dursun et al., which the level of knowledge of tuberculosis patients about tuberculosis was evaluated, a relationship was not found between the accuracy of the answers and age ${ }^{25}$. In the tuberculosis awareness assessment study of Enginyurt et al., it was revealed that $21.7 \%$ of those between the ages of 20 $29,20.8 \%$ of those between the ages of $30-39$, and $14.3 \%$ of those aged 40 and over are unconscious about tuberculosis awareness ${ }^{26}$.

In this study, which examines the information status according to gender, there was no statistically significant difference in terms of gender between the amount of change observed in the percentage of tuberculosis knowledge level after the training compared to before the training $(p>0.05)$. In the study of Nyasulu et al., which they evaluated the level 
of knowledge and perception of tuberculosis of primary school students, significant difference was not found between gender and tuberculosis knowledge level ${ }^{27}$. In the study of Yilmaz et al., a statistically significant difference was found between the gender variable and the mean score of tuberculosis knowledge level. Tuberculosis knowledge level average score of female nurses (80.26 \pm 14.51$)$ is significantly higher than the average score of tuberculosis knowledge level of male nurses $(74.92 \pm 16.01)^{23}$.

When tuberculosis knowledge levels before and after training were compared in terms of garede level, the average percentage of tuberculosis knowledge level of the $11^{\text {th }}$ grade students after the training was found to be significantly higher than those of the $9^{\text {th }}$ grade $(p: 0.029 ; p<0.05)$. There was no significant difference between the other grades in terms of the percentage average of tuberculosis knowledge level after the training. In the study of Nyasulu et al., though onethird of the students in the fifth and sixth grade were less knowledgeable about tuberculosis than those in the eighth grade, this was not statistically significant. Therefore, it is thought that students' knowledge may be the same in all four grades $\left(5^{\text {th }}, 6^{\text {th }}, 7^{\text {th }} \text {, and } 8^{\text {th }}\right)^{27}$.

In this study, the average pre-training level of tuberculosis knowledge was found to be statistically significantly higher in those with a family history of tuberculosis disease compared to those without it $(\mathrm{p}: 0.001 ; \mathrm{p}<0.01)$. This situation showed that those who have a family or close relatives with tuberculosis have more accurate information about the disease. In the studies of Dursun et al., it has been reported that those with a family history of tuberculosis know more about the ways of transmission of the disease, the method of treatment and the duration of the disease than those without $i^{25}$. In the study of Aylk et al., it was revealed that there was no significant difference between the knowledge levels of the groups with and without a diagnosis of tuberculosis in the evaluation made on all questions ${ }^{7}$. In the study of Polat et al., it was determined that there was no statistically significant difference between whether the nurses have family or relatives with tuberculosis and their tuberculosis knowledge level ${ }^{14}$. In the study of Yllmaz et al., there was no statistically significant difference between the presence of tuberculosis in the firstdegree relatives of nurses and their level of knowledge, although it was close to significance (F:3.62; p:0.058) $)^{23}$.
This study has some limitations. The first of these is that the study is limited to students studying at a secondary education institution in Adana in the 20172018 academic year. The fact that the data were collected from only one school constitutes the most important limitation of the study. Another is that studies evaluating the level of knowledge about tuberculosis in Turkey have been conducted on healthcare professionals, mostly physicians, and students studying in health sciences ${ }^{1,26,14,28}$. Due to the lack of similar studies with secondary education students in Turkey, in our discussion, references to past studies conducted in Turkey were limited, and references were made to research on students and healthcare professionals who study in the field of health sciences.

In addition, since there is no national and/or international standard questionnaire that measures tuberculosis knowledge level, the questions in the studies are prepared by the researchers as a result of the literature reviews. If a questionnaire measuring the nationally and/or internationally accepted standard tuberculosis knowledge level is created, it may be possible to make an evaluation with the more extensive and comprehensive data collected.

In general, health campaigns and awareness programs are important tools for communicating health information to recall and reinforce existing knowledge and these programs should be repeated periodically. Trainings should be organized not only for students but also for other segments of the society; because this will ensure that correct information is updated and false information is also discussed and verified. Lack of training negatively affects the spread of infectious diseases ${ }^{29}$.

In conclusion, we must address the issue from all sides in the fight against tuberculosis. The training of the families and friends around the patient during the treatment is important as well as the patients treated $^{13}$. After the tuberculosis training given, it was determined that the students had significantly more knowledge about the contagiousness of the disease, the route of transmission, its symptoms, how it was diagnosed and DOT compared to before the training. Increasing public awareness about the diagnosis and treatment of tuberculosis, organizing nongovernmental organizations, screening and training seminars in collective living areas (nursing homes, prisons, etc.) can reduce patient-induced diagnosis delay. In community studies, it is important to provide training on preventive measures and clinical 
signs of tuberculosis, and to inform people about the disease, according to perception levels ${ }^{7}$. Parallel studies to be conducted in different centers that will contribute to increase the knowledge level of young adult society in controlling tuberculosis will better show the situation in the country.

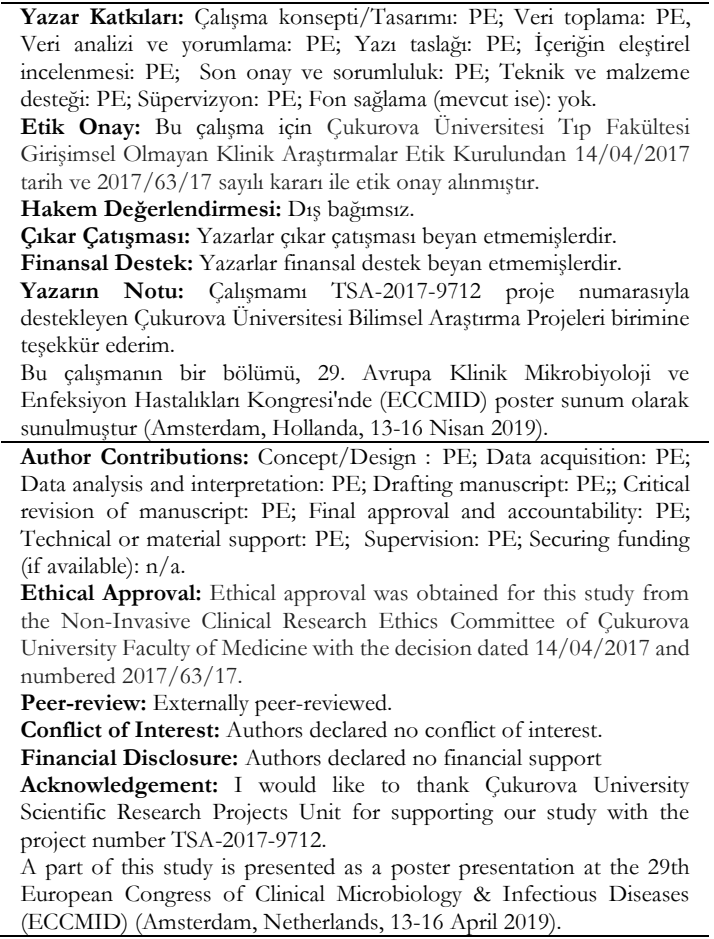

\section{REFERENCES}

1. Demir M, Aslan E, Taylan M, Yilmaz S, Bucaktepe Erten PG, Aydeniz N, et al. Tip fakültesi öğrencilerinin tüberküloz hastalığı hakkındaki bilgi düzeyleri. Dicle Med J. 2016;43:241-6.

2. WHO. Global Tuberculosis Report 2020. Geneva: World Health Organization; 2020.

3. Baylan O. Çok ilaca dirençli tüberkülozdan sonra yaygın ilaca dirençli ve tüm ilaçlara dirençli tüberküloz formları: Eski hastalığın yeni yüzleri. Mikrobiyol Bul. 2011;45:181-95.

4. Şimşek AÇ, Özkan S. Ankara ilinde yapılan aktif sürveyans uygulamasının tüberküloz hastalarının kayıt ve takibine katkısının değerlendirilmesi. Ankara Med J. 2019;71-82.

5. Özpınar S, Taner Ş, Yıldırım G, Anar MC, Alıparmak $\mathrm{O}$, Baydur $\mathrm{H}$. Tüberküloz damgalanma ölçeği: Geçerliliği ve güvenilirlik. Tuberk Toraks. 2015;63:192-8

6. Dilek A. Socially stigmatizing disease from the perspective of public health: tuberculosis. Klinik Gelişim. 2007;20:86-90.
7. Ayık S, Karasu I, Çil E, Mertoğlu A, Özsöz A. Hastaların tüberküloz hastalığ hakkında bilgi düzeyleri. İzmir Göğüs Hastanesi Dergisi. 2013;27:817.

8. Değer V, İnanç Battaloğlu B, Çiftçi S. Knowlodge of tuberculosis among health higher school students. J Clin Anal Med. 2015;6:358-62.

9. Kara F. Tüberküloz Tanı ve Tedavi Rehberi. Ankara, Sağlık Bakanlığı, 2019.

10. Wolde D, Tadesse M, Abdella K, Abebe G, Ali S. Tuberculosis among Jimma University undergraduate students: First insight about the burden of tuberculosis in Ethiopia Universities-cross-sectional study. International Journal of Bacteriology. 2017; Article ID 9840670, 6 pages.

11. Ma MJ, Yang Y, Wang HB, Zhu YF, Fang YQ, An $\mathrm{XP}$, et al. Transmissibility of tuberculosis among school contacts: An outbreak investigation in a boarding middle school, China. Infection, Genetics and Evolution. 2015;32:148-55.

12. Trost, J. E. Statistically nonrepresentative stratified sampling: A sampling technique for qualitative studies. Qualitative sociology, 1986;9:54-57.

13. Çiftçi F, Torun Ö, Bozkanat E, Açıkel CH, Başoğlu C, Kartaloğlu Z. Sağlık çalışanlarında tüberküloz bilgi düzeyi ve risk algilamas1. Turk Thorac J. 2007;8:221-6.

14. Polat Ş, Uçar Z, Denizci N, Tuna B, Çetin E, Geniş D. Bir üniversite hastanesindeki hemşirelerin tüberküloz hakkındaki bilgi düzeyi. Cumhuriyet Nurs J. 2017;6:18-25.

15. Tolossa D, Medhin G, Legesse M. Community knowledge, attitude, and practices towards tuberculosis in Shinile town, Somali regional state, eastern Ethiopia: A cross-sectional study. BMC Public Health. 2014;14:2-13.

16. Gothankar JS. Tuberculosis awareness program and associated changes in knowledge levels of school students. Int J Prev Med. 2013;4:153-7.

17. Dorji $\mathrm{T}$, Tshering $\mathrm{T}$, Wangdi $\mathrm{K}$. Assessment of knowledge, attitude and practice on tuberculosis among teacher trainees of Samtse College of Education, Bhutan. PLoS one. 2020;15:e0241923.

18. Organization $\mathrm{WH}$. Use of high burden country lists for TB by WHO in the post-2015 era: Summary. 2020.

19. Rana M, Sayem A, Karim R, Islam N, Islam R, Zaman TK, et al. Assessment of knowledge regarding tuberculosis among non-medical university students in Bangladesh: A cross-sectional study. BMC Public Health. 2015;15:2-7.

20. Uchenna OU, Ngozi CJ. Assessment of tuberculosisrelated knowledge, attitudes and practices in Enugu, South East Nigeria. J. Infect. Dis. Immun. 2014;6:1-9.

21. Adane K, Spigt M, Johanna L, Noortje D, Abera SF, Dinant GJ. Tuberculosis knowledge, attitudes, and practices among northern Ethiopian prisoners: Implications for TB control efforts. PloS One. 2017;12:e0174692. 
22. Pramanik D, Ghosh J. Knowledge and awareness of tuberculosis among pulmonary tuberculosis patients in a rural area of west Bengal. SAARC Journal of Tuberculosis, Lung Diseases and HIV/AIDS. 2015;12:13-9.

23. Yılmaz Taşkın F, Tuna Gülen A, Çevik Y, Kılıçarslan N. Göğüs hastalıkları hastanesinde görev yapan hemşirelerin tüberküloza ilişkin bilgi düzeyleri. İ.Ü.F.N. Hem. Derg. 2011;19:37-44.

24. Çiftçi F, Işıldak İşler Y, Torun Ö. Tüberkülozlu asker hastalarda tüberküloz bilgi düzeyi, risk algilaması ve eğitimin bu sürece etkisi. Turkiye Klinikleri J Med Sci. 2010;30:180-6.

25. Dursun AB, Güler ZM, Aydın Ö, Güve FS, Yılmaz A, Sertkaya D. Tüberküloz hastalarında tüberküloz hakkında bilgi düzeyinin değerlendirilmesi. Solunum Hastalıklar1 Dergisi. 2005;16:127-31.
26. Enginyurt Ö, İşcanlı MD, Kılıç M, Cakır L, Öztürk EH, Depe Y, et al. Tüberküloz farkındalık değerlendirmesi. Klinik Tip Aile Hekimliği Dergisi. 2016;8:25-35

27. Nyasulu P, Kambale S, Chirwa T, Umanah T, Singini $\mathrm{I}$, Sikwese $\mathrm{S}$, et al. Knowledge and perception about tuberculosis among children attending primary school in Ntcheu District, Malawi. J Multidiscip Healthc. 2016;9:121-31.

28. Topbaș E, Bingöl G, Bulut S. Tüberküloz bilgi düzeyinin belirlenmesi: Sağllk yüksekokulu örneği. Uluslararası Hakemli Hemşirelik Araştırmaları Dergisi. 2016;7:69-82.

29. Demir C, Yıldız H, Yürektürk S. Van Yüzüncü Yıl Üniversitesi Sağlık Hizmetleri Meslek Yüksekokulu öğrencilerinin bulaşıcı hastalıklar ile ilgili bilgi durumları. Van Tip Derg. 2020;27:458-65. 